\title{
Incarceration experiences among a community-recruited sample of injection drug users in Bangkok, Thailand
}

\author{
Kanna Hayashi ${ }^{1}$, M-J Milloy ${ }^{1,2}$, Nadia Fairbairn' ${ }^{1}$, Karyn Kaplan³, Paisan \\ Suwannawong ${ }^{3}$, Calvin Lai ${ }^{1}$, Evan Wood ${ }^{1,4}$ and Thomas Kerr*1,4
}

Address: ${ }^{1}$ Urban Health Research Initiative, British Columbia Centre for Excellence in HIV/AIDS, Vancouver, Canada, ${ }^{2}$ School of Population and Public Health, University of British Columbia, Vancouver, Canada, ${ }^{3}$ Mitsampan Harm Reduction Center/Thai AIDS Treatment Action Group, Bangkok, Thailand and ${ }^{4}$ Department of Medicine, University of British Columbia, Vancouver, Canada

Email: Kanna Hayashi - kanna.hayashi@gmail.com; M-J Milloy - mjmilloy@cfenet.ubc.ca; Nadia Fairbairn - n.fairbairn@gmail.com; Karyn Kaplan - karyn@ksc.th.com; Paisan Suwannawong - paisan.suwannawong@gmail.com; Calvin Lai - clai@cfenet.ubc.ca; Evan Wood - uhri-ew@cfenet.ubc.ca; Thomas Kerr* - uhri-tk@cfenet.ubc.ca

* Corresponding author

Published: 30 December 2009

BMC Public Health 2009, 9:492 doi:10.1 186/147|-2458-9-492
Received: 21 July 2009

Accepted: 30 December 2009

This article is available from: http://www.biomedcentral.com/I47I-2458/9/492

(c) 2009 Hayashi et al; licensee BioMed Central Ltd.

This is an Open Access article distributed under the terms of the Creative Commons Attribution License (http://creativecommons.org/licenses/by/2.0), which permits unrestricted use, distribution, and reproduction in any medium, provided the original work is properly cited.

\begin{abstract}
Background: Since 2003 Thailand has waged an aggressive "war on drugs" campaign focused on arresting and incarcerating suspected drug users and dealers. However, little is known about incarceration experiences among IDU in the wake of the recent war on drugs. Therefore, we sought to examine incarceration experiences among IDU in Bangkok, Thailand.

Methods: We examined the prevalence of incarceration among community-recruited IDU participating in the Mitsampan Community Research Project. Multivariate logistic regression was used to identify factors associated with a self-reported history of incarceration. We also examined the prevalence of injection drug use and syringe sharing within prisons.

Results: 252 IDU were recruited in August 2008; 66 (26.2\%) were female and the median age was 36.5 years. In total, 197 (78.2\%) participants reported a history of incarceration. In multivariate analyses, reporting a history of incarceration was associated with a history of compulsory drug treatment (adjusted odds ratio $[A O R]=4.93 ; 95 \%$ confidence interval $[\mathrm{Cl}]$ : $1.95-12.48$ ), non-fatal overdose $(A O R=3.69 ; 95 \% \mathrm{Cl}: 1.45-9.39)$, syringe sharing $(A O R=2.20 ; 95 \% \mathrm{Cl}: 1.12-4.32)$, and female gender $(A O R=0.41 ; 95 \% \mathrm{Cl}: 0.20-0.82)$. Among those who reported a history of incarceration, $59(29.9 \%)$ reported injection drug use in prison, and $48(81.4 \%)$ of these individuals reported sharing syringes in prison. Incarceration was not associated with the number of injections performed in the previous week $(p=0.202)$.

Conclusion: Over three-quarters of the IDU participating in this study reported a history of incarceration, and $30 \%$ of these individuals reported injection drug use within prison. Further, an alarmingly high level of syringe sharing within prison was reported, and incarceration was not associated with reductions in drug use. These findings provide further evidence of the need for community diversion strategies, as well as harm reduction programs, in Thai prisons.
\end{abstract}




\section{Background}

In many countries, drug law enforcement continues to be a dominant societal response to illicit drug use $[1,2]$. Consequently, injection drug users (IDU) are frequently arrested and incarcerated [3-5]. A large body of evidence indicates that incarceration is associated with elevated risks of drug-related harm among IDU, including the spread of blood-borne pathogens such as human immunodeficiency virus (HIV) and hepatitis $\mathrm{C}$ virus (HCV) [610]. For example, HIV outbreaks associated with injection drug use in prison have been observed in Scotland [11], Lithuania [12], and the Russian Federation [13]. Endemic sharing of injection equipment has been identified as a major factor contributing to high HCV incidence in prisons in Australia [14] and Scotland [15]. The burden of prison-related epidemics of infectious disease is essentially linked with the public health of communities due to high inmate turnover and the potential spread of prisonacquired infections among non-inmate populations.

The first major wave of HIV infection in Thailand is believed to have occurred among IDU inmates in Bangkok in 1988 [16]. Since then, several studies have suggested that incarceration has continued to be an important risk factor for HIV infection among Thai IDU [17-21]. The HIV prevalence among Thai IDU remains disproportionately high, standing between 30-50\% [2224]. Moreover, a recent study reported an HIV/HCV coinfection rate of $98.8 \%$ among HIV-positive IDU prisoners in Bangkok [25]. Despite these findings, Thailand has consistently pursued an aggressive enforcement-based response to illicit drug use $[17,26,27]$. The inmate population in Thailand has more than tripled between 1992 and 2002, with approximately $70 \%$ of these incarceration events attributable to drug-related charges [28,29].

The most aggressive "war on drugs" campaign in Thailand was initiated in 2003 by the former Thai Prime Minister Thaksin Shinawatra, which involved renewing and augmenting efforts to arrest and incarcerate suspected drug users and dealers [26]. This campaign also involved dramatically scaling up compulsory addiction treatment programming [30,31]. In 2008, the Thai government reinstituted this policy initiative [32,33]. While epidemiological evidence has linked incarceration with HIV infection among Thai IDU, little is known about rates of and factors associated with incarceration among IDU in the wake of these intensive law enforcement campaigns. Therefore, we sought to characterize the prevalence and correlates of incarceration among a community-recruited sample of IDU in Bangkok, Thailand with the aim of informing policies specific to addiction and public health.

\section{Methods}

Data for these analyses were obtained from the Mitsampan Community Research Project, a collaborative research effort involving the British Columbia Centre for Excellence in HIV/AIDS (Vancouver, Canada), the Mitsampan Harm Reduction Center (Bangkok, Thailand), the Thai AIDS Treatment Action Group (Bangkok, Thailand), and Chulalongkorn University (Bangkok, Thailand). During July and August of 2008, the research partners designed and undertook a cross-sectional study targeting local IDU in Bangkok recruited through peer-based outreach efforts and word-of-mouth. Invited participants were asked to attend the Mitsampan Harm Reduction Center, where they provided informed consent and completed an interviewer-administered questionnaire. The survey instrument elicited demographic data, information on drug use patterns, HIV risk behavior, overdose experiences, interactions with the criminal justice system (including police and incarceration), and experience with health care. Upon completion of the questionnaire, participants were provided a stipend of 250 Thai baht (about US\$7.50) and reimbursed for transportation costs. The study has been approved by the research ethics boards at the University of British Columbia and Chulalongkorn University.

The primary outcome of interest in the present analysis was self-reported history of incarceration (i.e., answering "Yes" to the question: "Have you ever been in prison overnight or longer?"). We compared IDU who reported a history of incarceration with those who did not using univariate statistics and multivariate logistic regression. Variables considered included: median age $(<36.5$ years vs. $\geq 36.5$ years); gender; education level ( $\geq$ secondary school vs. < secondary school); median daily expenses for purchasing drugs $(<300$ Thai baht per day vs. $\geq 300$ Thai baht per day); ever injected heroin; ever injected yaba (methamphetamine); ever injected midazolam; ever injected methadone; ever used drugs in combination; ever shared syringes; ever experienced a non-fatal overdose; ever involved in sex trade; ever in compulsory drug treatment; and ever on methadone treatment. All behavioral variables were coded as yes vs. no.

To examine the bivariate associations between each independent variable and a history of incarceration, we used the Pearson $\mathrm{X}^{2}$ test. Fisher's exact test was used when one or more of the cells contained values less than or equal to five. We then applied an a priori-defined statistical protocol that examined factors associated with a history of incarceration by fitting a multivariate logistic regression model that included all variables that were significantly associated with history of incarceration at the $p<0.05$ level in univariate analyses. Using Pearson's correlation coefficient, we also assessed whether reporting a history of incarceration was associated with reduced drug use (as measured by the number of injections performed in the previous week). All $p$-values were two-sided. In a sub-analysis, we also asked individuals reporting a history of incar- 
ceration if they had ever injected drugs and shared syringes in prison.

\section{Results}

In total, 252 IDU were recruited in August 2008, of whom $66(26.2 \%)$ were female. The median age was 36.5 years (IQR: 31.0-46.0 years). The majority of our sample ( $\mathrm{n}=$ 238; 94.4\%) grew up in the Bangkok Metropolitan Area. One hundred fifty-five $(61.5 \%)$ individuals reported injection heroin use and $86(34.1 \%)$ reported injection yaba and ice (i.e., methamphetamine) use at least daily in the past six months. Less than half of the participants $(\mathrm{n}=$ $111 ; 44.0 \%$ ) had ever received methadone treatment, and $116(46.0 \%)$ received drug or alcohol treatment in the past six months. In total, 197 (78.2\%) participants reported a history of incarceration.

Table 1 presents the univariate analyses of factors associated with reporting a history of incarceration. As shown, reporting a history of incarceration was positively associated with having been in compulsory drug treatment (odds ratio $[\mathrm{OR}]=4.91,95 \%$ confidence interval [CI]: 2.01-12.03), history of non-fatal overdose (OR $=4.40$, 95\%CI: 1.80-10.79), syringe sharing $(\mathrm{OR}=2.44,95 \% \mathrm{CI}$ : 1.30-4.58), and midazolam injection $(\mathrm{OR}=2.00,95 \% \mathrm{CI}$ : 1.08-3.69), and was negatively associated with female gender $(\mathrm{OR}=0.48,95 \% \mathrm{CI}$ : 0.25-0.91).

Table 2 presents the multivariate analyses of factors independently associated with reporting a history of incarceration. As shown, reporting a history of incarceration was independently and positively associated with having been in compulsory drug treatment (adjusted odds ratio [AOR] = 4.93, 95\%CI: 1.95-12.48), ever overdosed $(\mathrm{AOR}=3.69$, 95\%CI: 1.45-9.39), syringe sharing $(\mathrm{AOR}=2.20,95 \% \mathrm{CI}$ : 1.12-4.32), and was negatively associated with female gender $(\mathrm{AOR}=0.41,95 \% \mathrm{CI}: 0.20-0.82)$. Among those who reported a history of incarceration, 59 (29.9\%) reported injection drug use in prison and 48 (81.4\%) of these individuals reported sharing syringes in prison. Reporting a history of incarceration was not associated with the number of injections performed in the previous week $(p=0.202)$.

\section{Discussion}

More than three-quarters of the community-recruited IDU participating in this study reported a history of incarceration. In multivariate analyses, after adjustment for relevant covariates, reporting a history of incarceration was positively associated with a history of compulsory drug treatment, syringe sharing and non-fatal overdose. Females were less likely than males to have been incarcerated. Among those reporting a history of incarceration, $30 \%$ reported injection drug use within prison. Further, an alarmingly high level of syringe sharing (81.4\%) was reported among those who injected drugs while in prison. Reporting a history of incarceration was not found to be associated with reduced frequency of injection drug use.

Our findings are consistent with previous studies suggesting that incarceration is very common among Thai IDU [17], and that high levels of drug injection and syringe sharing occur within prisons in this setting $[17,34]$. However, the proportion of Thai IDU with a history of incarceration observed in this study is considerably higher than the one observed by Beyrer et al. during the period 19992000 , who reported that $55 \%$ of IDU in Northern Thailand had a history of incarceration [17]. This increase in the prevalence of incarceration among Thai IDU may be attributable to differences in sample characteristics or geographic differences in drug law enforcement efforts between Northern Thailand and Bangkok, or the higher prevalence observed in our study may reflect the 2003 war on drugs and subsequent crackdowns that have taken place throughout the country in spite of policy efforts to redirect people who use drugs to treatment centers rather than prison. Regardless, given the high prevalence of HIV infection in this setting $[23,24]$ and the high levels of injection drug use and syringe sharing that occur within prisons, it is unlikely that the epidemic of HIV among Thai IDU can be controlled under the current enforcement-based policy approach. As has been suggested previously [35], controlling or averting epidemics of HIV infection among IDU requires minimizing the transmission of HIV within correctional environments, as well as reducing the rate of incarceration of drug-using populations [36]. Our findings provide further evidence of the urgent need for harm reduction measures, including syringe exchange, in Thai prisons. Indeed, previous evaluations indicate that prison-based syringe exchange programs have been successfully implemented in a range of settings, including low- and middle-income countries [37].

Our findings also suggest that compulsory drug treatment experience is common among Thai IDU with a history of incarceration. This may be due to the fact that Thai IDU are often arrested and held within prison before being diverted to a compulsory treatment setting. Recent reports suggest that IDU spend on average 45 days in prison prior to the diversion [38]. The compulsory treatment system is intended to treat drug users as "patients" and reduce drugrelated harms in overcrowded prisons $[31,39]$. However, given the evidence indicating high rates of syringe sharing among IDU within Thai prisons in our study, as well as in previous studies $[19,34]$, the program of arrest and compulsory drug treatment system, which requires incarceration of IDU, may fail to prevent HIV risk behavior occurring within prisons and thus may serve to perpetuate rather than reduce HIV infection rates among Thai IDU in 
Table I: Factors associated with history of incarceration among IDU in Bangkok, Thailand $(n=252)$

\begin{tabular}{|c|c|c|c|c|c|}
\hline \multirow[t]{2}{*}{ Characteristic } & \multicolumn{2}{|c|}{ History of incarceration $\mathrm{n}(\%)$} & \multirow[t]{2}{*}{ OR } & \multirow[t]{2}{*}{$95 \% \mathrm{Cl}$} & \multirow[t]{2}{*}{$p$-value } \\
\hline & Yes: 197 (78) & No: 55 (22) & & & \\
\hline \multicolumn{6}{|l|}{ Median age } \\
\hline$<36.5$ years & $100(5 \mathrm{I})$ & $26(47)$ & 1.15 & $0.63-2.09$ & 0.647 \\
\hline$\geq 36.5$ years & $97(49)$ & $29(53)$ & & & \\
\hline \multicolumn{6}{|l|}{ Gender } \\
\hline Female & $45(23)$ & $21(38)$ & 0.48 & $0.25-0.91$ & 0.024 \\
\hline Other & $152(77)$ & $34(62)$ & & & \\
\hline
\end{tabular}

\section{Education}

\begin{tabular}{|c|c|c|c|c|c|}
\hline$\geq$ Secondary & $122(62)$ & $27(49)$ & 1.69 & $0.92-3.08$ & 0.089 \\
\hline$<$ Secondary & $75(38)$ & $28(5 \mathrm{I})$ & & & \\
\hline \multicolumn{6}{|c|}{ Median daily expenses for purchasing drugs } \\
\hline$<300$ Thai baht & $94(48)$ & $31(56)$ & 0.71 & $0.39-1.29$ & 0.258 \\
\hline$\geq 300$ Thai baht & $103(52)$ & $24(44)$ & & & \\
\hline \multicolumn{6}{|c|}{ Ever injected heroin } \\
\hline Yes & $186(94)$ & $48(87)$ & 2.47 & $0.91-6.70$ & 0.077 \\
\hline No & II (6) & $7(13)$ & & & \\
\hline
\end{tabular}

Ever injected yaba (methamphetamine)

\begin{tabular}{|c|c|c|c|c|c|}
\hline Yes & $128(65)$ & $33(60)$ & 1.24 & $0.67-2.28$ & 0.497 \\
\hline No & $69(35)$ & $22(40)$ & & & \\
\hline
\end{tabular}

Ever injected midazolam

\begin{tabular}{|c|c|c|c|c|c|}
\hline Yes & I 39 (7I) & $30(55)$ & 2.00 & $1.08-3.69$ & 0.027 \\
\hline No & $58(29)$ & $25(45)$ & & & \\
\hline
\end{tabular}

Ever injected methadone

\begin{tabular}{|c|c|c|c|c|c|}
\hline Yes & $33(17)$ & $6(11)$ & 1.64 & $0.65-4.15$ & 0.293 \\
\hline No & $164(83)$ & $49(89)$ & & & \\
\hline
\end{tabular}

Ever used drugs in combination

\begin{tabular}{|c|c|c|c|c|c|}
\hline Yes & $|4|(72)$ & $34(62)$ & 1.56 & $0.83-2.91$ & 0.167 \\
\hline No & $56(28)$ & $21(38)$ & & & \\
\hline
\end{tabular}

Ever shared syringes

\begin{tabular}{llllll}
\hline Yes & $107(54)$ & $18(33)$ & 2.44 & $1.30-4.58$ & 0.005 \\
\hline
\end{tabular}


Table I: Factors associated with history of incarceration among IDU in Bangkok, Thailand $(n=252)$ (Continued)

\begin{tabular}{|c|c|c|c|c|c|}
\hline No & $90(46)$ & $37(67)$ & & & \\
\hline \multicolumn{6}{|c|}{ Ever overdosed } \\
\hline Yes & $69(35)$ & $6(11)$ & 4.40 & $1.80-10.79$ & 0.001 \\
\hline No & $128(65)$ & $49(89)$ & & & \\
\hline \multicolumn{6}{|c|}{ Ever involved in sex trade } \\
\hline Yes & $20(10)$ & II (20) & 0.45 & $0.20-1.01$ & 0.054 \\
\hline No & $177(90)$ & $44(80)$ & & & \\
\hline \multicolumn{6}{|c|}{ Ever in compulsory drug treatment } \\
\hline Yes & $74(38)$ & $6(11)$ & 4.91 & $2.01-12.03$ & $<0.001$ \\
\hline No & $123(62)$ & $49(89)$ & & & \\
\hline \multicolumn{6}{|c|}{ Ever on methadone treatment } \\
\hline Yes & $89(45)$ & $22(40)$ & 1.24 & $0.67-2.27$ & 0.494 \\
\hline No & $108(55)$ & $33(60)$ & & & \\
\hline
\end{tabular}

this setting. Further, the effectiveness of the current system also comes into question given that compulsory drug treatment often consists of a military-style boot camp with no evidenced-based addiction treatment being offered [38]. Taken together with our finding of a lack of an association between incarceration and reduction in injection drug use, our study indicates a need to reform the existing diversion program for drug-using offenders. Unfortunately, the evidence concerning commonly applied diversion programs, such as drug courts, is equivocal [40], and therefore there is a need for innovation in this area. However, as a recent report from the United Kingdom suggested, when diversion programs are applied within a climate shaped by draconian drug policy, such programs tend to be punishment-oriented and inflexible regarding individual treatment needs [41]. Therefore, broader structural changes to the over-arching policy envi- ronment are needed to ensure that responses to addiction focus on the health needs of drug users rather than punishment.

We also found that non-fatal overdose was associated with incarceration among Thai IDU. This finding is of significance given the dearth of evidence pertaining to overdose among Thai IDU. While we were unable to establish a temporal relationship between overdose and incarceration in this sample, mounting evidence from Western countries indicates that incarceration greatly exacerbates the risk of fatal and non-fatal overdose among IDU upon release from prison [42-47]. In particular, risk for heroin overdose is likely to be elevated upon release from prisons as a result of reduced tolerance [48]. A recent study from the US reported that drug overdose was a leading cause of death among former inmates [44]. Further research is

Table 2: Multivariate logistic regression analysis of factors associated with reporting a history of incarceration among IDU in Bangkok, Thailand $(n=252)$

\begin{tabular}{|c|c|c|c|}
\hline Characteristic & AOR & $95 \% \mathrm{Cl}$ & $p$-value \\
\hline Gender (female vs. other) & 0.41 & $0.20-0.82$ & 0.01 \\
\hline Ever shared syringes (yes vs. no) & 2.20 & $1.12-4.32$ & 0.02 \\
\hline Ever overdosed (yes vs. no) & 3.69 & $1.45-9.39$ & 0.01 \\
\hline Ever in forced treatment (yes vs. no) & 4.93 & $1.95-12.48$ & $<0.01$ \\
\hline
\end{tabular}


needed to elicit the linkage between overdose and incarceration among Thai IDU.

This study has several limitations. First, since this is an observational study, we cannot infer causal relationships between exposure and outcome. Second, the study relied on self-report, and therefore the results may be affected by socially desirable reporting. While the peer-administered interviews were expected to minimize such bias, we may still have underestimated the true prevalence of incarceration among Thai IDU or the prevalence of drug use or syringe sharing within prisons. Third, the study sample was not randomly recruited, which means our findings may not be generalizable to other populations of IDU in Thailand. Finally, we could not distinguish incarceration histories by type, duration, or location of incarceration. Future research should aim to address the effect that these modifiers might have on active IDU and their risk behaviors.

\section{Conclusions}

We observed alarmingly high levels of incarceration and syringe sharing in prison among a community-recruited sample of Thai IDU. Incarceration was independently associated with compulsory drug treatment experience, syringe sharing and non-fatal overdose, but was not associated with reductions in the frequency of injecting. These findings raise serious concerns regarding the adverse health consequences resulting from the enforcementbased approach to illicit drug use in Thailand and underscore the urgent need for community diversion programs (e.g., addiction treatment) and harm reduction measures (e.g., syringe exchange) in prisons.

\section{Competing interests}

The authors declare that they have no competing interests.

\section{Authors' contributions}

TK, NF and EW designed the study. CL and TK conducted the statistical analyses. $\mathrm{KH}$ and TK drafted the manuscript and incorporated all suggestions. All authors made significant contributions to the conception and design of the analyses, interpretation of the data, and drafting of the manuscript, and all authors approved the final manuscript.

\section{Acknowledgements}

We would particularly like to thank the staff and volunteers at the Mitsampan Harm Reduction Center for their support. We also thank Dr. Niyada Kiatying-Angsulee of the Social Pharmacy Research Unit, Faculty of Pharmaceutical Sciences, Chulalongkorn University, for her assistance with developing this project. We also thank Daniel Miles Kane, Deborah Graham and Tricia Collingham for their assistance with data management, and Prempreeda Pramoj Na Ayutthaya and Donlachai Hawangchu for their assistance with data collection.

\section{References}

I. Bewley-Taylor D, Trace M, Stevens A: Incarceration of drug offenders: costs and impacts. In Briefing paper no 7 Surrey: Beckley Foundation Drug Policy Programme; 2005.

2. DeBeck K, Wood E, Montaner J, Kerr T: Canada's 2003 renewed drug strategy--an evidence-based review. HIVIAIDS Policy Law Rev 2006, I I:5-12.

3. World Health Organization: Multi-City study on drug injecting and risk of HIV infection. Geneva: World Heath Organization; 1994.

4. Milloy MJ, Wood E, Small W, Tyndall M, Lai C, Montaner J, Kerr T: Incarceration experiences in a cohort of active injection drug users. Drug and Alcohol Review 2008:1-7.

5. Loxley W, Carruthers S, Bevan J: In the same vein: first report of the Australian study of HIV and injecting drug use. Perth: ASHIDU NCRPDA, Curtin University of Technology; 1995.

6. Allwright S, Bradley F, Long J, Barry J, Thornton L, Parry JV: Prevalence of antibodies to hepatitis B, hepatitis C, and HIV and risk factors in Irish prisoners: results of a national cross sectional survey. BMJ 2000, 32 I (7253):78-82.

7. Zamani S, Kihara M, Gouya MM, Vazirian M, Ono-Kihara M, Razzaghi EM, Ichikawa S: Prevalence of and factors associated with HIV$I$ infection among drug users visiting treatment centers in Tehran, Iran. AIDS 2005, I9(7):709-716.

8. Wood E, Li K, Small W, Montaner J, Schechter MT, Kerr T: Recent incarceration independently associated with syringe sharing by injection drug users. Public Health Reports 2005, I 20: I 50- I56.

9. Malliori M, Sypsa V, Psichogiou M, Touloumi G, Skoutelis A, Tassopoulos N, Hatzakis A, Stefanis C: A survey of bloodborne viruses and associated risk behaviours in Greek prisons. Addiction 1998, 93(2):243-25।.

10. Macalino GE, Vlahov D, Sanford-Colby S, Patel S, Sabin K, Salas C, Rich JD: Prevalence and Incidence of HIV, Hepatitis B Virus, and Hepatitis $\mathbf{C}$ Virus Infections Among Males in Rhode Island Prisons. Am J Public Health 2004, 94(7): I 2 I 8-1223.

II. Taylor A, Goldberg D, Emslie J, Wrench J, Gruer L, Cameron S, Black J, Davis B, McGregor J, Follett E, Harvey J, Basson J, McGavigan J: Outbreak of HIV infection in a Scottish prison. BMJ I995, 3 I 0(6975):289-292.

12. MacDonald $\mathrm{M}$ : A study of health care provision, existing drug services and strategies operating in prisons in ten countries from Central and Eastern Europe. Finland: Heuni; 2005.

13. Bobrik A, Danishevski K, Eroshina K, McKee M: Prison health in Russia: the larger picture. Journal of Public Health Policy 2005, 26(I):30-59.

14. O'Sullivan BG, Levy MH, Dolan KA, Post J], Barton SG, Dwyer DE, Kaldor JM, Grulich AE: Hepatitis C transmission and HIV postexposure prophylaxis after needle- and syringe-sharing in Australian prisons. Medical Journal of Australia 2003, I 78( I I):546-549.

15. Champion JK, Taylor A, Hutchinson S, Cameron S, McMenamin J, Mitchell A, Goldberg D: Incidence of Hepatitis C Virus Infection and Associated Risk Factors among Scottish Prison Inmates: A Cohort Study. Am J Epidemiology 2004, I59(5):514-519.

16. Wright N, Vanichseni S, Akarasewi P, Wasi C, Choopanya K: Was the 1988 HIV epidemic among Bangkok's injecting drug users a common source outbreak? AIDS I994, 8(4):529-532.

17. Beyrer C, Jittiwutikarn J, Teokul W, Razak MH, Suriyanon V, Srirak N, Vongchuk T, Tovanabutra S, Sripaipan T, Celentano DD: Drug use, increasing incarceration rates, and prison-associated HIV risks in Thailand. AIDS and Behavior 2003, 7(2):|53-16I.

18. Choopanya K, Des Jarlais DC, Vanichseni S, Kitayaporn D, Mock PA, Raktham S, Hireanras K, Heyward WL, Sujarita S, Mastro TD: Incarceration and Risk for HIV Infection Among Injection Drug Users in Bangkok. JAIDS Journal of Acquired Immune Deficiency Syndromes 2002, 29(I):86-94.

19. Buavirat A, Page-Shafer K, van Griensven GJP, Mandel JS, Evans J, Chuaratanaphong J, Chiamwongpat S, Sacks R, Moss A: Risk of prevalent HIV infection associated with incarceration among injecting drug users in Bangkok, Thailand: case-control study. BMJ 2003, 326(7384):308.

20. Weniger B, Limpakarnjanarat K, Ungchusak K, Thanprasertsuk S, Choopanya K, Vanichseni S, Uneklabh T, Thongcharoen P, Wasi C: The epidemiology of HIV infection and AIDS in Thailand. AIDS I99I, 5(Suppl 2):S7I-85. 
21. Vanichseni S, Kitayaporn D, Mastro TD, Mock PA, Raktham S, Des Jarlais DC, Sujarita S, Srisuwanvilai LO, Young NL, Wasi C, Subbarao S, Heyward WL, Esparza L, Choopanya K: Continued high HIV-I incidence in a vaccine trial preparatory cohort of injection drug users in Bangkok, Thailand. AIDS 200I, I 5(3):397-405.

22. Perngmark P, Celentano DD, Kawichai S: Risk factors for HIV infection among drug injectors in southern Thailand. Drug and Alcohol Dependence 2003, 7 I(3):229-238.

23. Punpanich W, Ungchusak K, Detels R: Thailand's response to the HIV epidemic: yesterday, today, and tomorrow. AIDS Education and Prevention 2004, 16(Supplement A): I 19-136.

24. National AIDS Prevention and Alleviation Committee: UNGASS Country Progress Report Thailand: Reporting Period: January 2006 - December 2007. 2008 [http://data.unaids.org/pub/ Report/2008/thailand 2008 country progress report en.pdf].

Office of Technical Development to Support HIVIAIDS Responses, Department of Disease Control, Ministry of Public Health

25. Paungtubtim $\mathrm{W}$, Thaisri $\mathrm{H}$, Vongsheree $\mathrm{S}$, Sawanpanyalert $\mathrm{P}$, Rojanawiwat A, Sri-ngam P, Jaisue R, Chadbanchachai C, Kongpromsook W, Lerwitworapong J: High incidence and prevalence of hepatitis $C$ virus infection among Bangkok inmates, Thailand. The $X V$ International AIDS Conference. Bangkok, Thailand 2004.

26. Human Rights Watch: Not enough graves: the war on drugs, HIVIAIDS, and violations of human rights. 2004, 16 :.

27. Vongchak T, Kawichai S, Sherman S, Celentano DD, Sirisanthana T, Latkin C, Wiboonnatakul K, Srirak N, Jittiwutikarn J, Aramrattana A: The influence of Thailand's 2003 'war on drugs' policy on selfreported drug use among injection drug users in Chiang Mai, Thailand. International Journal of Drug Policy 2005, 16(2): I I5-121.

28. Reid G, Costigan G: Revisiting the hidden epidemic: a situation assessment of drug use in Asia in the context of HIVIAIDS. Australia: The Center for Harm Reduction; 2002.

29. International Centre for Prison Studies, King's College London: World Prison Brief: Prison Brief for Thailand. 2002 [http:// www.kcl.ac.uk/depsta/law/research/icps/worldbrief/ wpb country.php?country=114]. Septmber I, 2008

30. Kitada M: Prison population in Asian countries: facts, trends and solutions. UN Programme Network Institute's Technical Assistance Workshop. Vienna, Austria 2001.

3I. Narcotics Addict Rehabilitation Act B.E. 2545 (2002). Thailand.

32. War on drug to start on April 2. The Nation. Bangkok 2008.

33. Three-month war on drugs launched. The Nation. Bangkok 2008.

34. Thaisri H, Lerwitworapong J, Vongsheree S, Sawanpanyalert P, Chadbanchachai C, Rojanawiwat A, Kongpromsook W, Paungtubtim W, Sri-ngam P, Jaisue R: HIV infection and risk factors among Bangkok prisoners, Thailand: a prospective cohort study. BMC Infectious Diseases 2003, 3(I):25.

35. Wood E, Montaner J, Kerr T: HIV risks in incarcerated injectiondrug users. The Lancet 2005, 366(9500):1834-1835.

36. Maru DS-R, Basu S, Altice FL: HIV control efforts should directly address incarceration. The Lancet Infectious Diseases 2007, 7(9):568-569.

37. Canadian HIV/AIDS Legal Network: Needle and syringe programs and bleach in prisons: reviewing the evidence. Canadian HIVIAIDS Legal Network; 2008.

38. Pearshouse R: Compulsory drug treatment in Thailand: observations on the Narcotic Addict Rehabilitation Act B.E. 2545 (2002). Toronto: Canadian HIV/AIDS Legal Network; 2009.

39. Sungkawan D: Thai community-based correctional programmes for narcotics addicts in response to the 2002 Rehabilitation Act: a system approach. In Resource Material Series Volume 64. Tokyo, Japan: United Nations Asia and Far East Institute for the Prevention of Crime and the Treatment of Offenders (UNAFEI); 2004:94-I07.

40. Anderson JF: What to do about "much ado" about drug courts? International Journal of Drug Policy 200I, I 2(5-6):469-475.

4I. McSweeney T, Turnbull PJ, Hough M: The treatment and supervision of drug-dependent offenders: $A$ review of the literature prepared for the UK Drug Policy Commission. London: Institute for Criminal Policy Research, King's College London; 2008.

42. Kerr T, Fairbairn N, Tyndall M, Marsh D, Li K, Montaner J, Wood E: Predictors of non-fatal overdose among a cohort of polysubstance-using injection drug users. Drug and Alcohol Dependence 2007, 87(I):39-45.
43. McGregor C, Darke S, Ali R, Christie P: Experience of non-fatal overdose among heroin users in Adelaide, Australia: circumstances and risk perceptions. Addiction 1998, 93(5):701.

44. Binswanger IA, Stern MF, Deyo RA, Heagerty PJ, Cheadle A, Elmore JG, Koepsell TD: Release from prison - a high risk of death for former inmates. N Engl J Med 2007, 356(2): I57-165.

45. Farrell M, Marsden J: Acute risk of drug-related death among newly released prisoners in England and Wales. Addiction 2008, I 03(2):25I-255.

46. Ochoa KC, Davidson PJ, Evans JL, Hahn JA, Page-Shafer K, Moss AR: Heroin overdose among young injection drug users in San Francisco. Drug and Alcohol Dependence 2005, 80(3):297-302.

47. Seaman SR, Brettle RP, Gore SM: Mortality from overdose among injecting drug users recently released from prison: database linkage study. BM] I998, 3 I 6(7 | 29):426-428.

48. Darke S, Hall W: Heroin overdose: Research and evidencebased intervention. Journal of Urban Health 2003, 80(2): 189-200.

\section{Pre-publication history}

The pre-publication history for this paper can be accessed here:

http://www.biomedcentral.com/1471-2458/9/492/pre pub

Publish with BioMed Central and every scientist can read your work free of charge

"BioMed Central will be the most significant development for disseminating the results of biomedical research in our lifetime. "

Sir Paul Nurse, Cancer Research UK

Your research papers will be:

- available free of charge to the entire biomedical community

- peer reviewed and published immediately upon acceptance

- cited in PubMed and archived on PubMed Central

- yours - you keep the copyright 